\title{
Hume on What There Is
}

\author{
John H. Dreher \\ University of Southern California, Los Angeles, CA, USA \\ Email: dreher@usc.edu
}

How to cite this paper: Dreher, J. H. (2020). Hume on What There Is. Open Journal of Philosophy, 10, 243-265. https://doi.org/10.4236/ojpp.2020.102017

Received: April 27, 2020

Accepted: May 18, 2020

Published: May 21, 2020

Copyright ( 2020 by author(s) and Scientific Research Publishing Inc. This work is licensed under the Creative Commons Attribution International License (CC BY 4.0).

http://creativecommons.org/licenses/by/4.0/

(c) (i) Open Access

\begin{abstract}
This paper argues that a neglected, in fact a barely noticed, concept in Hume's A Treatise of Human Nature plays a crucial role in understanding his philosophy. The crucial concept arises in connection with the difficulty that Hume encounters in referring to the "external world." Indeed, as Quine observes concerning Hume, if all that can be thought are our own ideas and impressions (viz. perceptions), then it is unclear how we can possibly think of objects that are not our own ideas and impressions. Hume writes: The farthest we can go toward a conception of external objects, when supposed specifically different from our perceptions, is to form a relative idea of them, without pretending to comprehend the related objects. Generally speaking, we do not suppose them specifically different; only attribute to them different relations, connections and durations (Hume, 17401 , 1, 2, 6.19, 20 p. 49). The first purpose of this paper is to explain what Hume means by "relative ideas." The second purpose is to explain their importance in Hume's ontology, that is, his understanding of what there is. The third purpose is to consider Quine's argument against Hume in his seminal paper "On What There Is." Finally, the fourth purpose of the paper is to assess the role of relative ideas and in particular the relative idea of external existence in Hume's ontology.
\end{abstract}

\section{Keywords}

Hume, Relative Ideas, Quine, External Existence

\section{Introduction: Making Sense of Relative Ideas}

As indicated in the above quotation, relative ideas are of signal importance for Hume in forming "conceptions" of external objects, which is to say ideas of what

${ }^{1}$ Hume published the first two books of the Treatise anonymously in 1739 . The entire work was published under Hume's name in 1740. 
there is. Those conceptions of external objects are "specifically" different from external objects themselves. Here the key word is "specifically," by which Hume means of different species. For example, when I am trying to form an idea of an external object, say of my hat with the words "Squam Lake" embroidered in the top-henceforth my "Squam Lake hat" - I am not struggling to form an idea of my idea of a hat from Squam Lake; I am struggling to form an idea of an "external object," which is a particular hat. Obviously, if I were looking to buy a hat with the label "Squam Lake" embroidered on the front, I would not be looking to buy an idea of a hat with the label "Squam Lake" on the front; on the contrary, I would be looking to buy a hat with the label "Squam Lake" embroidered on the front. Suppose that I found and bought my "Squam Lake hat" and subsequently lost or misplaced it. Perhaps I would decide to look for it in my closet, where it belongs. Of course, in looking in the closet I would not be looking for my idea of my Squam Lake hat, I would be looking for my Squam Lake hat.

Having drawn the distinction between the idea of a thing and the thing itself, it is natural to wonder just what is the difference between by idea of a thing and the thing itself. It may appear that the distinction collapses. Indeed, if I conceive my Squam Lake hat to have a certain characteristic, say that it is white with red embroidery, then my idea of it includes the idea of its being white with red embroidery. As Hume explains:

"as every idea is derived from a preceding impression, it's impossible our idea of a perception, and that of an object, or external existence can ever represent what are specifically different from each other. Whatever difference we may suppose between them, it's still incomprehensible to us; and we are obliged either to conceive an external object merely as a relation without a relative, or to make it the very same with a perception or impression" (Hume, 1740, 1.2.6.10, p. 49.)

Here we learn how "relative" is actually used by Hume. He is nether contrasting "relative" with "absolute," as in the distinction between relative and absolute conceptions of space, nor is he using "relative" to mean "context dependent," as it is sometimes used in the thesis that the meaning of a word is relative to its use or to the language game in which it is used. Hume uses "relative" to refer to a relatum, as in the claim that Desdemona is the relatum of the relation expressed by "Othello loves Desdemona," which asserts that Othello is related to Desdemona (the object to which Othello is related, the relatum) by the relation "loves." A relation without a relative is inconceivable because it asserts that something is "related" without being related to anything.

\subsection{Hume's Dilemma: The Chasm between Metaphysics and Solipsism}

Hume has landed in a terribly awkward ontological position. If he considers his 
impressions and ideas ${ }^{2}$ to be the sole objects with which he is acquainted, then his ontology will be unassailable as far as it goes, but it won't go far enough because it will not include "external objects" that are in some way represented by impressions and ideas. On the other hand, if objects exist apart from impressions and perceptions, then, being of different kinds or species, they cannot be usefully compared with perceptions. One fork in the road leads to an incoherent metaphysics; the other to solipsism.

Perhaps, all is not lost. Might we think of existence itself as a relation between an impression or perception and an external object? In that case, my idea of my existing Squam Lake hat, if true, is instantiated by my Squam Lake hat; if false, it is not instantiated. Might we then say that an idea actually refers if the external object to which it purports to refer actually exists? By way of analogy, might we say that "perceptions" actually refer to external "existences"? If so, the perception of the existence of an external object is true if the object exists; otherwise the perception of its existence is false. In an admittedly strained sense, existence will then be the glue that attaches the idea of an object to the external object that the idea represents. Unfortunately, apart from the awkwardness of the suggestion (indeed, it resists coherent expression in English), Hume flatly rejects it. Hume reasonably assets that there is no difference between the concept of a thing and the conception of it as an existing thing. There is no difference between my idea of my Squam Lake hat and of my idea of my existing Squam Lake hat. Hume goes further: He asserts that my belief "of the existence" of an object adds nothing new to my idea of the object (Hume, 1740, 1,3,5,7, p. 61). In other words, my belief that my Squam Lake hat exists adds nothing to the content of my idea of it, and therefore what it adds (nothing) cannot account for the apparent fact that my idea of my Squam Lake hat represents something or other. It is at this point that Hume differs markedly from Locke. Locke claims that one's idea of a thing represents it in a way that can be likened to the resemblance of a picture to the thing portrayed (Locke, 1689: pp. 122ff). As we have just seen, Hume rejects Locke theory because there is no way to compare one's idea of a thing with the thing itself; one's idea only be compared to another idea.

Hume's way of navigating the strait between incoherent metaphysics and solipsism lies in the narrows of relative ideas. My idea of my Squam Lake hat refers to an "external object," but we have no way of knowing the nature of the relation it bears to that object. All this appears to lead ineluctably to the conclusion that there is a "something or other," which is "out there somewhere or other," to

\footnotetext{
${ }^{2}$ Hume refers indifferently to impressions and ideas as perceptions. Ideas are formed from impressions either as direct copies or else by the mental manipulation of ideas (that is, augmentation, diminution, transposition, or compounding). Impressions themselves are either the objects of sensory experience or of reflection: "An impression first strikes upon the senses, and makes us perceive heat or cold, thirst or hunger, pleasure or pain of some kind or other. Of this an impression there is copy taken by the mind, which remains after the impression ceases, and this we call an idea. This idea of pleasure or pain, when it returns upon the soul, produces new impressions of desire and aversion, hope and fear, which may be properly called impressions of reflection because derived from it." (Hume, 1740, 1.1.2.1, p.11).
} 
which my idea of my Squam Lake hat refers, but we really cannot know anything about it. Yet, this cannot be right, and Hume does not think that it is right, because Hume is a Newtonian. Following Newton, Hume thinks that we have "knowledge" (which is to say) true justified beliefs about the "external world;" that is, of the world of ordinary things and the ways in which they behave. Their behavior is explained by the laws of Newtonian physics, which, Hume claims, is the paradigm of genuine human knowledge.

When we claim that an impression or idea exists, we mean that it is present to mind and that it is immediately (without mediation) apprehended. When we refer to the objects of Newtonian physics like planets and rocks or like the relations between their masses and acceleration, we do not mean that they are immediately apprehended as ideas and impressions, but rather that they exist "in relation" to our conception of them. In other words, we have only relative ideas of planets and rocks (and their properties), and if we think that those things exist, we have only a relative idea of their external existence,-as we shall see later on, perhaps a justified relative idea of their external existence, but nonetheless, merely a relative idea.

\subsection{The Ghost of Descartes}

Hume's account of the relative idea of external existence at first may appear to lead to solipsism. What reason do we have for believing that our ideas refer to any external thing? Indeed, what reason can Hume possibly have for believing that there is anything external to one's own mind at all? As we have seen, Hume affirms the world of ordinary objects and Newton's account of their behavior, but what reason can he have for believing that if he insists that we only a "relative" idea of their existence? Indeed, there is a problem that is deeper still: Hume must distinguish even himself from his idea of himself. Must he not say that he merely has a relative idea of himself and of his external existence? Here Hume is haunted by the ghost of Descartes. In the Principles of Philosophy Descartes observes that "there seem to be no marks by means of which we can with certainty distinguish being asleep from being awake." (Descartes, 1644: p. 194). Likewise, in Meditations on First Philosophy Descartes writes: "I see plainly that there are never any sure signs by means of which being awake can be distinguished from being asleep." The result, Descartes concludes, is that (when looking for signs), "I begin to feel dazed, and this very feeling only reinforces the notion that I may be asleep." (Descartes, 1641: p. 13). Now if everything is but a dream, then all belief is delusory, and nothing exists except for my dreams and myself, but at least Descartes is left not only with his dreams but also with knowledge of his own existence, which reveals the privileged epistemological perspective of the "I." That privileged perspective is the essence of the "Cogito," the conviction that whatever "I" doubt or dream, it must be that it is "I" who doubts or dreams, and therefore it must be that "I" exist.

Descartes claims that it is just the presupposition of the privileged perspective 
that relieves us from the radical skepticism at first articulated by Pyrrho (360c. 272 BCE), which denies that we can have any knowledge at all, especially the paradoxical "knowledge" that we know that we cannot know anything at all. This appears to be the situation in which Hume finds himself. In the Appendix to Part One of the Treatise where Hume writes:

We only feel a connexion or a determination of the thought, to pass from one object to another. It follows, therefore, that the thought alone finds personal identity, when reflecting on the train of past impressions that compose a mind, the ideas of them are felt to be connected together, and naturally introduce each other In short, there are two principles, which I cannot render consistent; nor is it my power to renounce either of them, viz. that all our distinct perceptions are distinct existences, and that the mind perceives any real connexion among distinct existences (Hume, 1740, Appendix, 20, p. 400).

The problem, Hume concedes, is that our ideas neither appear to "lie in something simple and individual" (viz. the self, as Descartes had argued), nor is there any "real connexion" among our ideas that is perceptible (Hume, 1740, Appendix, 21, p. 400). Here the difference between Descartes and Hume lies in the willingness of Descartes and the unwillingness of Hume to acknowledge the presupposition of a personal reference point, the "I," which unites a series of perceptions into the perceptions by a single entity.

Hume's broader skeptical doubts cannot be relieved by following Descartes. For Descartes, the "I" has a clear and distinct idea of God, which is clearly and distinctly perceives by the natural light, from which it follows that God exists. For Hume, however, there is no "I" to have the idea of God. Hume's skepticism appears to be very close to Pyrrhonian skepticism. Hume faces a philosophical problem of the first order, by which I mean that it does not derive from a particular philosophical perspective but rather from the underlying "human" perspective that gives rise to philosophy in the first place.

Perhaps it is tempting to think that Hume's (and Descartes') worries are obsessive and excessive. What reasonable person could be troubled by mere reveries of the imagination, for example that life is but a dream? Perhaps Descartes and Hume just lived in a disconcerting time of intellectual revolution, and their worries about skepticism simply derived from the absence of settled opinion. In this connection it is perhaps helpful to remember that neither Descartes nor Hume were among the first humans to seize upon the distinction between sleeping and waking states and worrying about its implications for understanding the relation of the perceiver to the perception and of the perception to its object.

On the other hand, Pyrrho himself, the founder of radical skepticism in the West was also tormented by skeptical doubts. Moreover, it would be a serious mistake to think that Pyrrhonian skepticism is solely a Western preoccupation; it is rather an emblem of the human condition. Consider, Pyrrho's contemporary, Zhuang Zhou, who is also known as Zhuangzi or more frequently in the West, 
Chuang Tzü (c.369 BCE - 286 BCE). In the second chapter of his famous Stories, Zhuangzi offers one of the most charming and endearing of his collection, the so-called "Butterfly Story."

Once Zhuangzi dreamed that he was a butterfly flitting and fluttering about happy with himself and doing as he pleased. He didn't know that he was Zhuang Zhou. Suddenly he woke up and there he was, solid and unmistakable Zhuang Zhou. But he did not know if he was Zhuang Zhou who had dreamt (that) he was a butterfly or a butterfly dreaming that he was Zhuang Zhou. Between Zhuang Zhou and the butterfly there must be some distinction (Zhuangzi, c.300 BCE: p. 44)!

Here Zhuangzi is questioning the very existence of a coherent, identifiable self with its unique perspective on the "world," which enables the "I" to distinguish what pertains to it and what pertains to others. Zhuangzi and other ancient Chinese skeptics retreat to the impressions of ordinary experience to relieve paralyzing doubt. Hume appears to take a similar approach, which he believes leads to a more moderate form of skepticism that he calls "academic skepticism." Academic skepticism sets aside paralyzing, paradoxical worries and simply responds directly and even uncritically to the stimuli of daily life. Ironically, we are tempted to thinking of academic skepticism as a liberating mind set. How can Hume be criticized reasonably for failing to draw a recondite distinction between "external" reality and himself when he has no idea of external reality (except in the relative sense) and no idea of himself? Indeed, taking a Wittgensteinian approach, we might argue, that there really isn't any possibility for Hume to distinguish himself from external reality because there is not a discoverable, real distinction between the external existence of oneself and everything else. Following Wittgenstein, for there to be a "real distinction" there must be a "language game" in which a legitimate move is from perceiver to perception and from perception to the object that is perceived, ${ }^{3}$ but perhaps there just isn't a legitimate move in the language game of philosophy that takes us from perceiver to perception and from perception to its object.

\section{Hume Enamored and Ensnared by the Experimental Method}

Unfortunately for Hume, it is absolutely impossible for him to brush off the problem of "external" reality. That is because the project of the Treatise is to show that philosophy can be done without resorting to the "tedious" method of the "Schoolmen," who adopted the methods of medieval metaphysicians. The

\footnotetext{
${ }^{3}$ The notion of a language game on which this comment relies is nicely explicated by Jean-Francois Lyotard in his "Report on Knowledge." "There Lyotard explicates Wittgenstein as follows: What he (Wittgenstein) means is by this term is that each of the various categories of utterances can be specified in terms of rules specifying their specific properties and the uses to which they can be put-in exactly the same way as the game of chess is defined by a set of rules determining the properties of each of its pieces, in other words, the proper way to move them.” (Lyotard, 1984: p. 1550). Therefore, the challenge is to define the conditions under which philosophical analysis allows us to ascribe a perception to a perceiver and an object to the perception!
} 
Treatise embraces the liberating example of natural science, and the "experimental method of reasoning" that is championed by Newton himself (Newton, 1713: p. 393). Hume takes Newtonian science and its method to be the model of knowledge; not only does it teach us about the world, but also it liberates us from the dogmatic teachings of "the Schoolmen." Hume aspires to become known as the "Newton" of the moral sciences (Mossner, 1980: p. 73f).

The experimental method is based upon observation and experiment, by which data pertaining to the nature and structure of "external reality" are gathered and systemized by rigorous analysis. If there is no external reality, there is nothing to which the experimental method is to be applied and nothing for "natural philosophers" to investigate. When astronomers investigate the motions of the planets, they are not describing their ideas of the planets and their motions. When chemists sought the caloric, they were not seeking their idea of heat; they were trying to measure heat; not their idea of heat. Likewise, there is a distinction between the solar system and one's idea of the solar system. Physics is not about our idea of the solar system, but it is rather about the solar system itself. ${ }^{4}$ Physics is the investigation of bodies in motion, and if there aren't any bodies in motion, then is nothing for physics to study. Hume hopes to deal with all this via his teaching that our ideas of bodies in motion are relative and that our idea of their external existence is a relative idea.

Ironically, what threatens to stand stubbornly in Hume's way does not threaten Descartes at all. Why? The answer can be found in one of the central ideas of Cartesian philosophy. Descartes himself argues that because we have an innate idea of extension, and because the essence of space and of matter is extension, it must follow that truths about extension apply to space and the matter that it holds. (For Descartes, the attribute of extension is accurately described by Euclidean geometry. Ergo physical space must be Euclidean. A piece of plywood that is a "rectangular triangle" with sides of 3 and 4 feet necessarily has a diagonal of 5 feet $^{5}$ ) (Descartes, 1641, p: 47 fn. 2).

If the Cartesians could explain the concept of matter at a place in space, then surely a tough-minded empiricist like Hume should be able to give an account of the "external world," but what could that account be? Hume's answer is that all our knowledge of the external world presupposes the existence of "body."

We may well ask, What causes induce us to believe in the existence of body?

But this vain to ask, Whether there be body or not? That is a point, which

\footnotetext{
${ }^{4}$ There are of course disciplines that focus on our ideas and their development. Intellectual history, for example, is about the development of our ideas and hence deals with the development of our ideas about the solar system.

${ }^{5}$ Descartes' idea of space is not Newtonian. Like Leibniz, Descartes insists that space is ultimately defined by the relations among objects, and that those relations are in turn accurately represented in Euclidean geometry, see (Descartes, 1644: p. 229). Of course, Cartesian philosophy of science was ultimately undermined by its insistence that space is Euclidean, but it was not until the nineteenth century that the possibility of non-Euclidean geometries was developed by Lobachevsky (1829) in "On the Principles of Geometry,” which appeared in the Kazan Messenger in 1829 (Boyer, 1968: p. 586).
} 
we must take for granted in all our reasonings (Hume, 1740, 1.4.2.1, p. 125).

This passage is one of the most important and perhaps the most difficult to interpret. The problem of course is the word "body." We know that Hume is committed to the existence of bodies: of planets and rocks, and even microscopic creatures. We also know that without bodies there is really nothing for physical science to study, but why then, does Hume not just ask what induces us to believe in the existence of bodies? Surely an enlightened response would be that Newtonian science presupposes the existence of bodies; but that is not what Hume says: He says that we must take "body" for granted in all our reasonings.

I believe the right way to begin is not to ask what Hume means by "body" but rather why he does not find a more familiar way of asking his question. That more familiar way would be to ask what induces us to believe in the existence of matter. Unfortunately, that formulation of the question is not available to Hume since he denies the existence of a "material substratum," in other words, "matter." I suggest that "body" is used in the above passage in place of "matter."Perhaps it is tempting to think that the concept of "body" is related to "bodies" as the concept "dog" is related to dogs, but this analysis is wrong-headed, because "body" is not related to "a body" as universal to particular. A better approach is to think of "body" as a mass term, like "gold." We may consider gold to be a discontinuous "substance" and pieces of gold (coins, necklaces, rings, et cetera) as fragments of gold. As fragments of gold are related to gold, so bodies are related to body. Therefore, the existence of body maybe reasonably thought to be presupposed by experimental science. Ultimately for Hume, experimental science is the study of body, keeping in mind that the "nature" of body is revealed only indirectly by the behavior of bodies.

Hume's view is that if we refuse to take the existence of body for granted, there is nothing for scientists to investigate. Hume claims that "the idea of existence is the very same with the idea of what we conceive to exist" (Hume, 1740, 1.2.6, 4, p. 48). Yet, as we have insisted previously, Hume also claims that we can only conceive ideas, and ideas do not resemble anything except other ideas. So, it cannot be that my idea of the external world resembles the external world. That is why it is that Hume concludes his discussion of skepticism with regard to the senses with the observation that we can form only a relative idea of external existence. Physics is about bodies, which located in various places at various times, but contrary to Locke, we do not know whether or not our ideas of those bodies and their qualities actually resemble the bodies themselves. ${ }^{6}$

At this point it is neither Descartes' nor Zhuangzi's theory, but rather Hume's theory that seems to be hopelessly bizarre. How are we to understand a sentence like "Physics is about the universe"? Hume's only recourse is to the mysterious

${ }^{6}$ Indeed, it is at this point that Hume explicitly rejects and argues at length against the Lockean theory of "double existence." Hume's point is that our perception is an idea, and nothing can resemble an idea other than another idea. So, the notion that an idea can resemble something that is "material" is incoherent (Hume, 1740, 1.2.4.5, p. 126). 
attributions of the relative idea of external existence. Hume is driven to the conclusion that Whatever the universe may be; it must be whatever is described by Newtonian science. ${ }^{7}$

\section{What We Can Neither Live with Nor without}

I believe that Hume's conception of the relative idea of external existence is just what he needs to account for the ontology of Newtonian science. There are, however, two worries about it. The first is that it is too powerful, that it can justify too much. If we can resort to a Humean analysis of bodies, then what is to stand in the way of similar analyses justifying beliefs in chimera-of demons, monsters, witches, and even demigods? What is so special about the bodies of Newtonian science that shows that they, and they alone, should be deemed to be the proper objects of the relative idea of external existence? For what it is worth, Hume has an answer that is straightforward and quintessentially Humean: What is so special about the bodies of Newtonian science is that they are "Newtonian," and that the data and principles of Newtonian science are the only means to justified beliefs about the "external world."

The second worry is not so readily dismissed. It appears that Hume's analysis is vulnerable to troublous metaphysical consequences. especially when it comes to the possibility of the relative of idea of the external existence of the soul, the relative idea of the external existence of God, and even the relative idea of the external existence of infinite space and time. Can Hume account for those putative objects without going too far; that is, without affirming the relative idea of the external existence of demons, monsters, witches, and even demigods? The answers that Hume gives are: First, that we do not have an idea of the Cartesian self or soul but at most the evanescent idea of the self, of a thing that perceives, feels, and thinks. Hume claims that at present we do not even have a relative idea of the self, although we cannot help but think that we have a justified relative idea of its external existence. Secondly, we have neither a relative idea of God nor a justified relative idea of the external existence of God. Thirdly, we ultimately must admit that we do not have a relative idea of space or time much less a justified relative idea of its external existence; indeed, we do not have a coherent idea of space or time. The notion of a justified idea of external existence has

\footnotetext{
${ }^{7}$ We find further evidence supporting this approach in Hume's critical analysis of Spinoza's account of substance, where Hume rejects the conception of the "substratum," which

supports the most different modifications, without any difference in itself; and varies with them without any variation. Neither time, nor place, nor all the diversity of nature are able to produce any composition or change in its simplicity and identity (Hume, 1740, 1.4.5.18, p. 158).

Hume carries on and refers to the substratum as that "hideous hypothesis that is almost the same as with that of the immateriality of the soul." Indeed, selves and bodies play similar roles in Hume's philosophy; yet he denies the existence of mental and spiritual substances, and even refers to mental and spiritual substances as "hideous" hypotheses. Nonetheless, he acknowledges the need to distinguish objects (viz, external existences) from impressions and perceptions of them (Hume, 1740, 1.4.5.19, p. 158).
} 
just made an unexpected and apparently inexplicable reappearance. What is it that distinguishes a mere relative idea of the external existence of a thing from the justified relative idea of its external existence? Perhaps surprisingly, Hume thinks that the answer is obvious. A relative idea of the external existence of a thing can be justified only by the experimental method of reasoning. The justification turns a mere idea into a belief, which is a justified relative idea of the external existence of the object. So, which ideas are affirmed by this standard? The answer is that the relative idea of the external existence of the objects of ordinary perceptions is affirmed. Furthermore, when bodies and their qualities are validated by Newtonian science, ${ }^{8}$ they are found to be probable, and their probability is said to be philosophical, in which case the relative ideas of their external existence has been justified by the experimental method. On the other hand, Hume considers an assessment of probability to be "unphilosophical" if it does not derive from general principles of scientific investigation that are confirmed by the experimental method but rather are induced by mere "chance" associations. Beliefs of that sort are prejudices. They lack confirmation by the experimental method, which is sufficient to show that those beliefs are unjustified (Hume, 1740, 1.3.1.8, p. 100). On the other hand, if a favorable judgment of the idea has been reached by the experimental method, then the positive assessment of its probability is philosophical, which is to say that the relative idea of its external existence has been confirmed by the experimental method of reasoning, that is, by ordinary methods of Newtonian science.

\subsection{The Self}

The clearest case for the relative existence of an object that is a "non-body" is surely the self. The very validation of the relative external existence of bodies, which are the objects of Newtonian science, suggests that there must have been a scientist to produce ideas of those bodies and their constitutions. Moreover, the very existence of a Humean, philosophical validation of Newtonian science suggests that there must be a validator (Hume himself). All that must have suggested itself to Hume. He might then have conceived of himself, whoever he may $b e$, to be, among other things, the author of $A$ Treatise of Human Nature. Just as naturally, there must have been someone, Newton, whoever he might have been, who was the author of Newtonian science. So, now we have two selves, and obviously there is no need to stop there. Yet Hume does not appeal to a notion of the relative idea of the external existence of selves (much less to souls). ${ }^{9}$ Hume

${ }^{8}$ Hume does not offer us an elaborate (or even detailed) account of Newtonian science or its method. He takes both for granted. According to Hume, genuine science hopes to establish general rules by which to predict and to explain. Those general rules are properly extracted from observations and the generalizations. Hume briefly discusses these matters in (Hume, 1740, 1.3.4.1-3, p. 58) and (1, 3.15, 1-12, pp. 166-118). A full account of the details of Hume's account of scientific reasoning is beyond the scope of this paper.

${ }^{9}$ The idea of the soul, at least in the Cartesian sense, is obviously unavailable to Hume, because the relative idea of its external existence would not be natural (that is, of something in nature) and therefore would not fall within the scope of empirical science. 
finds that a complete conception of the self is elusive, but that cannot be an explanation of his skepticism about the notion of the self. The relative external existence of light was and still is elusive, but no one doubts its external existence.

I want to address this problem at two levels: The first is at the motivational level; the second is at the justificatory level. At the motivational level, Hume wanted to do everything that he could to disarm his metaphysical opposition. Yet, Hume's doctrine of relative ideas of the external existence of bodies arguably puts his philosophical opponents in a position to argue for the existence of souls. Why couldn't they claim that the soul just is whatever unites a particular series of perceptions into a unified whole? Here Hume's skepticism appears to be disarmed by his own conception of the relative ideas of the external existence of objects. That brings us to the justificatory part of the analysis. At the end of the passage from the Appendix that has already been cited (Hume, 1740, Appendix, 20 , p. 400), Hume claims that although he cannot identify the simple thing in which our perceptions in here and cannot produce the principle that will unite them over time, he nevertheless concedes that one day his skepticism about the self might be overcome. He writes of his own skepticism: "I pretend not, however, to pronounce it absolutely insuperable. Others, perhaps, or myself, upon more mature reflection, may discover some hypothesis, that will reconcile those contradictions (viz. about the self)." (Hume, 1740, Appendix, 21, p. 400).

What might those more mature reflections involve? Well, let's begin by reviewing what they will not involve: They will not involve reference to a substratum underlying mental phenomena, (as we have discovered) a "hideous" doctrine that is "almost the same as the immateriality of the soul" (Hume, 1740, 1.5.4.19, p. 158). The problem with the external existence of the soul is that whatever may be the sources of our perceptions, they cannot reside in a simple object. So, there is nothing for those sources to instantiate. The soul is not the counterpart of the body, because the body whatever it may be, is "in space," somewhere or other; however, the soul has no place. Even so, Hume does not deny that at some future time, a respectable account of the self might be given. That account, I suggest, might resemble current functionalist or epiphenomenalist accounts, and identify states of self as manifestations or effects of neurological states or events that are casually connected with "intentional" actions. ${ }^{10}$ Accounts along those lines would not complicate Hume's ontology (which includes commitment to bodes), but obviously would involve problems of their own. In fact, Descartes had already tried to produce an account of the soul that linked it to the body with disastrous consequences. How could the soul and the

\footnotetext{
${ }^{10}$ Epiphenomenalist accounts treat states of mind as phenomena that are dependent upon biological structures. The nature of the dependence is a matter is of some controversy. At the very least, the state of mind is dependent for its existence of a non-empty neurological state; so, if the neurological state is null (i.e., brain dead) there is no epiphenomenon to be experienced (For further discussion: See Robinson (2019)). Functionalist accounts typically take a mental state to be defined by the causal role it plays in responding to purely physical stimuli (like electromagnetic radiation or vibrations through a medium like air). For a detailed discussion: See Levin (2018).
} 
body causally interact if they are different substances and hence have nothing in common? ${ }^{11}$ Hume, however, could rely upon his own regularity theory of causation to negotiate issues surrounding the interaction of the mental and physical. Might Hume not say that the self is that thing (whatever it may be) that experiences ideas (pertaining to the will or to the understanding) that are generated from within the brain or more broadly the neurological structure of the human body? Indeed, that is a solution, which if scientifically validated, would come up to Newtonian standards of scientific explanation, but unfortunately there was nothing of the sort available in the eighteenth century. Perhaps Hume conjectured that there might be at some future time someone else or even Hume himself who could identify the neurological structures that serve the purpose of the self and thereby give us a coherent relative idea of the self and "validate" the relative existence of the self.

\subsection{God}

Although Hume thinks that he might conceive of a possible strategy to defend the relative idea of the external existence of self, he does not appear to think that there is room for God at all. Even so, it is right to remind ourselves that Hume does not completely dismiss the utility of religion. Paul Russell, who believes that discrediting dogmatic religion is one of Hume's most important objectives in the Treatise, concedes that Hume acknowledges that insofar as religious communities provide solace in times of trouble, they have genuine utility (Russell, 2008: pp. 295-300). Even so, it is right to emphasize that whatever utility Hume finds in the practice of religion, he does not have any patience at all for the dogmas of religion, particularly those dogmas that he believes have led to intolerance, oppression, and catastrophic wars (especially the Thirty Years War). Nevertheless, many would agree that the strict uncompromising views of various Christian sects (particularly Roman Catholicism) are not sufficient in themselves to justify the rejection of underlying faith in God. Indeed, why not conceive the relative idea of God to be whatever explains the existence of the vast constellation of bodies, that is of the Creation? This would appear to respect the unity of Hume's ontology while avoiding criticism of the faith and the faithful.

Hume wrote extensively on religion; however, the upshot of his writings appears to be that for him there just is not any justification for belief in the existence of God. Fully justifying that broad and somewhat controversial claim is beyond the scope of this paper; however, the main difficulties that Hume finds with the idea of God are emphasized in the Dialogues Concerning Natural Reli-

\footnotetext{
${ }^{11}$ Descartes conception of causation is an example of the $17^{\text {th }}$ century Imprint Theory of Causation, which colorfully claims that the cause leaves its imprint upon the effect. Hence the effect can be "found" in the cause. Hume famously denies this theory, replacing with his own early version of what has come to be known as a regularity theory. A regularity conception of causation associates prior events that are causes with consequent effects solely on the basis of statistical significance, without worrying about conceptual connections between prior and subsequent events. Detailed comparison of these competing conceptions of causation is beyond the scope of this paper. For a detailed introduction, see: Christopher Hitchcock (2018).
} 
gion. There Hume criticizes traditional arguments for the existence of God. He dismisses teleological arguments principally because they are "over-determined,"12 and he pointedly criticizes, even mocks, their plausibility. Moreover, he offers a broad assault on the Cartesian idea that God necessarily exists on the grounds that all assertions of existence must be contingent. Furthermore, Hume pointedly rejects the suggestion that the idea of God might be a relative idea of the Creator. Hume insists that there is no reason to think that the universe ever was created. He argues against Aristotle's first cause argument as he flatly denies that a causal sequence, even if infinite, must have a source. To say that we cannot explain the infinite sequence itself does not show that we cannot explain each event within the sequence. There is no reason to think that there is a need to refer to the source of an infinite causal sequence or nexus. In other words, there is nothing for the relative idea of God to be about, and hence no reason to suppose that God, whatever He may be, is the source of the infinite causal nexus that includes the universe. Finally, Hume dismisses all the so-called "ontological proofs" of the existence of God. Ontological "demonstrations" of God's existence, from Anselm on, argue that it is God's nature to exist and that God therefore necessarily exists, but Hume claims that all assertions of existence are matters of fact and therefore contingent. As Hume claims in An Enquiry Concerning Human Understanding, all existence claims have "contraries" that are "ever so conformable to reality"-meaning that there is nothing about the nature of reality itself that is inconsistent with the existence or non-existence of anything at all (Hume, 1748: pp. 188-192). It is fair and even uncontroversial to say that Hume rejects the traditional teleological, cosmological, and ontological arguments for the existence of God. ${ }^{13}$ Paul Russell writes convincingly in the concluding chapter of The Riddle of Hume's Treatise: Skepticism, Naturalism and Irreligion:

I have interpreted Hume's philosophy in the Treatise as fundamentally an effort to discredit the metaphysical and moral paraphernalia of orthodox religious systems and to redirect human investigations to the study of the "science of man," whereby we may develop a secular, scientific account of the foundations of moral and social life (Russell, 2008: p. 285).

\subsection{Space and Time}

Even if Hume can "fudge" when it comes to idea of the self and can reasonably dismiss the relative idea of the external existence of God, it appears that he must not do the same for space and time. The physics that Hume admires is fundamentally about the motions of bodies, which means changes in distance over time. Hume addresses the problems raised by space and time early in the Treatise, although he virtually ignores it in all his other writings. The reason is

\footnotetext{
${ }^{12}$ The point is that virtually anything can be construed to manifest the will of God, which gives rise to multiple, conflicting conceptions of God. In other words, everything can be construed to have and to be a purpose. Hume's point, I believe, is that teleological accounts to not actually produce a relative idea of God, much less a justified relative idea of the external existence of God.
} 
obvious. Bodies, which are obviously presupposed by the experimental method of reasoning, are relatively uncontroversial. No one who takes Newtonian science seriously can doubt the existence of bodies. The laws of physics are not about how our ideas are related, but rather how the things designated by our ideas are related to each other. Those things are bodies; however, space and time are quite different. In the case of space, Hume is forced to deal with the "clear and distinct perceptions" of Descartes; in the case of time, Hume faces the skepticism of Leibniz: What then do Hume's competitors have to say about space and time?

As we have seen, according to Descartes, extension is an attribute, it is the essence of matter or material substance. An individual thing, a body or physical object, is a mode or way of existing. The idea of extension is innate, and the properties of extension can be known a priori. A priori knowledge about extension is constituted by Euclidean geometry, As Descartes himself explained, geometry and arithmetic (algebra) are essentially connected. In this respect, Descartes' work on conic cones was of special interest during the period because sections like parabolas describe the motions of falling bodies and ellipses describe the orbits of planets. All this mathematical knowledge is essential to the development of seventeenth century science, and we shall have more to say

\footnotetext{
${ }^{13}$ The Dialogues Concerning Natural Religion are written in a form that enables Hume to avoid explicitly identifying himself with positions that he knew would be abhorrent to many of his readers. Indeed, as Kemp Smith makes clear in the edition cited, Hume struggled with the Dialogues for years and finally allowed their publication in the year of his death (Hume, 1776: p. v). Admittedly, it would take more than a paper to analyze the Dialogues and fully justify the claims above. However, like Paul Russell, whose exhaustive work on the subject appears to me to be irrefragable, I think that Hume believes that philosophy that is done properly leaves no room for "proofs" of the existence of God. This of course does not prove that there is no room for religious faith-only that there is no room, as Russell acknowledges by implication in the passage below, that there is no place for religious faith in the "science of man." Russell goes on to argue that Hume's philosophy is not only irreligious but also atheistic. I believe that this more dramatic claim is uncertain if only because Hume elsewhere acknowledges the utility of religious faith. More importantly, Newton himself boldly asserts religious claims in the second edition of the Mathematical principles of Natural Philosophy (Newton, 1714: p. 289), in the Optics (1713b), and even more controversially in his famous letters to Bentley (Newton, 1692: p. 52f) and (Newton, 1693: p. 53), in which he suggests that God might on occasions actually intervene into the operations of nature. If what is good enough Newton is good enough for Hume when it comes to the external existence of bodies, why shouldn't it be that what is good enough for Newton is also good enough for Hume when it comes to the external existence of God? True: It might be argued that at least we have an idea of bodies from science, which is not true in the case of God; however, even when it comes to science, Newton argues that the laws of nature can be interpreted prescriptively as well descriptively, meaning that Earth and surrounding heavenly bodies are moved not only in ways described by the laws of Newtonian physics, but also prescribed by God's command. That the laws of nature are interpreted prescriptively as well as descriptively well into the eighteenth century is emphasized by Ott, who points out that both Boyle and Cudworth also argue that whatever "governs events, needs an enforcer." Descartes and Malebranche agree, and insist that the appeal to laws actually requires the repeated or even incessant intervention of the divine hand. None of these philosophers suggests that laws might "appear on their own," which Ott persuasively argues is an "alternative regarded on all hands as absurd." Ott concludes that even Newton, in his letters to Bentley, still thinks that the laws of nature require implementation by an agent at every moment. Ott concludes that the notion that laws might themselves necessitate events is deemed to be incoherent far into the eighteenth century (Ott, 2009: p. 248).
} 
about it shortly. For now, however, is sufficient to emphasize Descartes' view that our knowledge of extension is a priori. Descartes claims that innate knowledge of extension grounds a priori knowledge of physical space, which is to say that knowledge about extension automatically applies to nature. For Descartes extended reality "houses" matter or material substance, and that "housing" is space.

Descartes' account of the relation of innate ideas to natural science is obviously unavailable to Hume. For Hume, all ideas derive from experience and hence the idea of space must derive from experience! Hume, as one might have expected, also takes his inspiration from Euclid. Following Euclid, all that we need to generate the concept of space is the idea of a point. Unfortunately, however, a point is an object with zero dimensions. One might ask, as virtually every beginning student of geometry does ask: Just how does a point differ from nothing at all? Hume's answer to that question appears to depend upon his theory of ideas.

Ideas, Hume claims, are "derived" from impressions, and so the idea of a point must be derived from an impression, but just what impression could that be? Hume claims that we can start by thinking of the smallest ("most point-like") entity. We can, for example, imagine a dot on a piece of paper. As the paper is gradually moved away, the dot appears to become smaller and smaller, and at a certain point is reaches its smallest point before vanishing, and that, according to Hume, is how we get the idea of a point (Hume, 1740, 1.2.2.4, p. 24).

There is an obvious objection to the account. If we were to look at a piece of paper under a microscope, points would become visible that are invisible to the unaided eye. This means that the concept of a point cannot be defined "objectively" because what counts a point will be the smallest extended visible thing relative to certain conditions of observation.

A microscope or telescope, which renders them visible produces not any new rays of light, but only spreads those, which always flowed from them, and by the means both parts to impressions, which to the naked eye appear simple and uncompounded, and advances to a minimum, what was formerly imperceptible (Hume, 1740, 1.2.2.4, p. 24).

Points look more like secondary than primary qualities, but never mind! Perhaps we can give greater objectivity to the idea of a point by applying one of the Humean "operations" of the mind to it. Even though Euclidean points now seem to be mere fictions, we imagine a Euclidean point as the result of "diminishing" the idea of a point "without limit." We cannot actually experience Euclidean points, but perhaps we can conceive of them indirectly by "reducing" a minimally observable point as far as we please, as a Leibniz would undoubtedly say, to $\varepsilon$.

It is natural to object that this operation does not make much sense. After all, the process of reducing the point without limit can never end. However small a 
point becomes, there is always farther to go. I think that Hume is troubled by this fact; however, I do not think that he believes that it undermines his theory. Hume is not worse off than Leibniz or Newton on this count. For example, if we want to know the velocity of an accelerating object is at a given moment, which is to say its instantaneous velocity, we shall need to locate the point on the curve describing its acceleration. The tangent of that curve will touch the curve at a single point, which is the instantaneous velocity of the object at that point. So, physics itself depends upon the concept of a point, a thing without dimension that can be used to "generate" objects with dimension. Admittedly this line of reasoning does not get Hume off the hook, but then Newtonian physics is on the same hook. Although Hume's account of the underlying concepts of physics does not come up to his own high standards, it hardly seems worse than competing empiricist theories. On the other hand, rationalists, might well have argued that Hume really is trapped where they are not-if only because rationalists can always resort to innate ideas. Still, claiming that an idea is innate but inconceivable is hardly a promising beginning for a theory claiming to validate a priori knowledge of nature. One way or another, for eighteenth century philosophers of science, geometry is still all about Euclid: A line is a sequence of points and is one dimensional. A plane is generated by an intersection of two lines. A volume is generated by the intersection of two planes. ${ }^{14}$

Now that we have more or less accounted for the notion of space, we can turn to the notion of time. Hume tries to develop his concept of time by analogy to the development of the concept of space. We need to start with something analogous to a point, and that of course is a "moment." It is obviously the present, which is the division between past and future. Unfortunately, the present appears to be past at its very inception. The present is analogous to a spatial point;

${ }^{14}$ For Descartes, The "generation" of an "infinite" volume can be described as the endless duplication of a fragment of lines. In this way Descartes hopes to explain the nature of extension, which constitutes essence of both body and of space. Descartes believes that there really cannot be "empty" space, (a vacuum) because there would then be nothing between the empty portion of space between two distinct points and therefore the points would "coincide," and hence the points would be one. This is of course the argument for a plenum (Descartes, 1644: pp. 227-232; especially p. 231). It is ironic that Locke's account is similar to Descartes. Locke accounts for the ideas of space, time, and infinity by treating the ideas of them as complex ideas framed by "repeating and joining together ideas that had come either from objects of sense or from reflection upon the operations of our minds." Thus, the notion of space is generated from the idea of a specific distance, which can be doubled and redoubled indefinitely. Locke follows the same strategy when it comes to duration and time. He writes "that it is the constraining of ideas of our own minds, appearing there one after the other is that the ideas of succession and duration, without which we would have no such ideas at all." Moreover, "the particular idea of a duration of anything is an idea of that portion of infinite duration that passes during the existence of that thing" (Locke, 1689: p. 263f). He explains in a footnote that none of this settles the issue concerning the possibility of infinite space and time "emptied of all finite places and durations." Locke qualifies his account in as follows: "Whether the mysteries of immensity, in which all finite spaces and eternity, in which all finite durations are lost, might subsist, though all finite spaces and durations should be annihilated, we cannot tell, but it is the ideas of particular spaces and durations that suggest these mysteries to man" (Locke, 1689: p. 264, fn 1). In other words, Locke is skeptical about the possibility of infinite but empty space and time. Descartes, on the other hand, denies the possibility of empty infinite space, but insists upon a finite "plenum." 
it is so to speak a "temporal point." The "nothing" which is a temporal point is of course essential to physics. The velocity of an object, $\mathrm{v}$, is equal to its change in its distance over time; in other words, $v=\Delta d / \Delta t$. As we have seen, if an object is accelerating, its instantaneous velocity at any point in space, $\Delta \mathrm{t}$, is 0 , which implies that $\Delta \mathrm{d} / \Delta \mathrm{t}$ is undefined at that point. Just as we need spatial points (without dimension), we need temporal "points" (without duration). Even so, if it is good enough for Newton, it must be good enough for Hume, because the Humean project is just to show that empiricist metaphysics and epistemology can give a satisfactory account of philosophical presuppositions of Newtonian physics. $^{15}$

Hume takes the project of philosophy to be to apply the experimental method of reasoning, the method of the Newtonians, to questions of "logic," including what we call "epistemology." That method is the method that yields conclusions based upon "philosophical probability," which is the measure of the reasonableness of belief. For Hume, the belief in the elusive relative idea of the external existence of bodies is the necessary presupposition of Newtonian science. Bodies are special because bodies in motion are essentially the subject of Newtonian science. This would seem to suggest that both space and time should be granted the coveted status of "external existences," and yet, Hume denies that we even have a relative idea of space and time. That is not to say, as we have seen, that we do not have ideas of places or of durations. But space and time are different from places and durations. Space is not a special place containing all the other places and time is not a special duration containing all the other durations. Hume concludes his discussion of space by observing of the attribute of extension that "we must always confess, that we have no idea of any real existence without filling it with sensible objects and conceiving its parts as visible or tangible." (Hume, $1740,1.2 .5 .9$, p. 47).

Concerning time, Hume writes that "as to the doctrine that it is nothing but the manner, in which some real objects exist; we may observe, that "its liable to the same objections as the similar doctrine with regard to extension." It is impossible, Hume concludes, for us to identify the impression from which the idea of time is derived. We can, however, explain the false appearance from the fact that we confuse the succession of impressions present to us with analogies to the positions of accelerating objects. In other words, we turn a line of points in space to a line of instants in time. Now it is possible for us to see why it is that we cannot agree that our ideas of space and time are relative ideas of external existences. The problem is that we do not have even relative ideas of space and time, although we certainly do have relative ideas of particular spaces and durations and justified relative ideas of their external exis-

\footnotetext{
${ }^{15}$ I think that the similarly of Hume and Kant on this point has not been sufficiently stressed. Both philosophers think that the primary business of philosophy is to identify and justify the philosophical assumptions that undergird Newtonian physics. This, of course, is not to deny the very great differences in their accounts; it is only to remember that they agree about the one thing that every credible philosophical theory must explain. That is why it is right to classify them both as Enlightenment philosophers.
} 
tence. ${ }^{16}$ (Hume, $1740,1.2 .5 .9$, p. 47 ).

\section{Quine on Everything and Hume on "Every Thing"}

Quine's view of the world as it is described by scientific theory is not that its existence is questionable, but rather that our ability to conceive of it in a single determinate way is radically underdetermined. Hume, on the other hand, claims that our idea of the external existence of bodies that have temporal and spatial location is itself a mere relative idea. Moreover, the notion that bodies, which are external existences, are in space and time amounts to something like a mere fiction, because our ideas of space and time are not even relative ideas, they are extravagant hypostatizations of finite, determinate places, and durations. ${ }^{17}$

In "On What There Is" Quine famously and unforgettably observes that the "ontological problem" really amounts to nothing more than finding an answer to the question "What is there?" The obvious answer, he observes, is "everything." Yet, as he notices, this answer is unsatisfying, despite its truth, because the answer really amounts to nothing more than "what there is what there is," and he wryly observes, as only he could, that his answer to the ontological question leaves "room for disagreement over cases" (Quine, 1964: p. 1).

Perhaps it is natural to think of Quine as a Humean; in any case many have thought so. Indeed, in "Epistemology Naturalized," where Quine distinguishes the "conceptual" from the "doctrinal," he claims that on the "conceptual side," Hume explained the nature of things or bodies "in sensory terms." According to Quine, Hume's explanation was "bold and simple: he identified bodies outright with sense impressions" (Quine, 1960: p. 712). It is easy to see what prompts this reading of Hume. Whatever we think pertains to the idea of a body is a part of that idea (or impression) of that body, whatever we think of a body is a part of our idea of that body, therefore, the distinction between thought and what is represented in and by thought seems to disappear. However, as plausible as that analysis is, it ignores a basic and overlooked distinction in Hume, which is the distinction between the idea of a body and the relative idea of the external existence of that body.

Quine's own approach must be distinguished from what he takes to be

\footnotetext{
${ }^{16}$ Ironically, Leibniz is in one way close to Hume when it comes to the analysis of time. For Leibniz physics is also about bodies in motion. However, bodies in motion are in some way manifestations of what is ultimately real, which are "simple spiritual substances" that Leibniz calls "monads." We know that monads are not physical because if they were, they would be infinitely divisible and hence not simple. We know that there must be simple substances because physical entities are divisible and nothing can be divisible without limit, otherwise there could be composites and are not composites of anything. Thus, for Leibniz, time is a notion that pertains not to the ultimately real but rather to the ultimately real as it is experienced and conceived by us (Leibniz, 1714: pp. 274-276).

${ }^{17}$ It is worth remembering that Kant in the Transcendental Aesthetic and the Antinomies of Pure Reason also rejects the notion of infinite space and of infinite time as legitimate ideas. That is what essentially turns him to his own theory that the notions of space and time are not concepts of objects but rather forms of our intuitions (Kant, 1781, beginning at A25, B 40, pp. 69-70, and beginning at A427, B453: pp. 376-402).
} 
Hume's bold approach of identifying bodies with impressions but also from the approach advocated here, which insists that Hume does carefully distinguish between the concept of body, the relative ideas of bodies and the relative idea of external existence of body and bodies. On the contrary, Quine advocates common sense realism both at the conceptual level and the doctrinal level. Ontology is read off from experience, and the beliefs that are fundamental to science are beliefs about conceptually primary entities. For Quine, bodies and their properties are the starting points of ontology, not things to be explained away as mere relative ideas. Quine nevertheless not only concedes, but even insists that common sense realism must be tempered by irresoluble difficulties that arise as we seek to identify objects by ostension and then go onto classify them, that is, to organize them into classes, Quine concludes in "The Scope and Limits of the Language of Science" that "We have found a tentative ontology in physical objects and classes." This takes ordinary things, physical objects, to be foundational. They may be grouped into classes, but what is maddingly elusive is the principle by which physical objects are to be grouped into classes that are truly described by the predicates that apply to them. Famously, Quine concludes in "Ontological Relativity" that a predicate like "rabbit" might be interpreted in radically different ways. In a nutshell the problem is that:

If you take the total scattered portion of the spatio-temporal world that is made up of rabbits, and that which is made of undetached rabbit parts, and that which is made up of rabbit stages, you come out with the same scattered portion of the world each of the three times. The only difference is how you slice it (Quine, 1968: p. 32).

It therefore turns out that meaning is indeterminate, and reference is "inscrutable." By ostension we at once refer to rabbits, their undetached parts and stages. Because we refer at once to multiple entities, we may take the meaning from the term that designates their class as being "indeterminate." Differentiating them comes at a more abstract level via their descriptions, but at that level their classification and differentiation appear to be based upon arbitrary choice and hence are subjective (Quine, 1954: pp. 32-34).

It may seem that the Quinean view is in fact the Humean view, but, as I have argued, the truth is exactly the opposite. For Hume we know that our impressions and ideas exist. Unlike Quine, whose commonsense realism takes the world of mid-sized physical objects to the "givens," Hume thinks that ordinary physical objects (bodies) are not givens but rather are inferred. We have impressions and ideas, but our ideas of physical objects and of their external existence are all relative, ultimately relative to the impressions that give rise to the ideas of those bodies. Indeed, for Hume our confident idea in the existence of an external world of bodies is relative to our impressions and ideas that are derived from those impressions. ${ }^{18}$

${ }^{18}$ Perhaps at this point is it forgivable to make and editorial comment, which is that Hume and Quine are both very great philosophers, philosophers for the ages, if only because they managed to explain so much despite assuming so very little. 


\section{The Importance of Hume's Doctrine of the Relative Idea of External Existence}

If the distinction between the relative idea of external existence and existence is so important, it is natural to ask: Why did Hume mention it so infrequently in the Treatise? Surely, he could have made more of it, particularly when it came to the idea of the self and the idea of space and time. Whatever we think will be unavoidably speculative. Unquestionably, it is best to keep speculation to a minimum, but it is nonetheless important for the present interpretation to say something about the fact that Hume does not emphasize what is obviously so important. The answer, suggested earlier, is that Hume was afraid that the relative idea of external existence could drum up a parade of chimera. For example: Why not say that we have a relative idea of the external existence of God? Why not say that we have a relative idea of the external existence the soul? How about relative ideas of the existence of angels, demons, and witches?-which is not yet to mention truly weird reveries of the imagination, like demigods! Hume wants to create an epistemology that excludes chimera lest they come to enjoy standing as respectable entities that would rival the bodies that are the legitimate objects of study by the empirical sciences. A parade of chimera would require their own science, perhaps akin or even a part of astrology, and Hume rejects reasonings of astrologers because they are not validated by the experimental method and hence their deliverances are examples of unphilosophical probability (Hume, $1740,1.3 .1 .8$, p. 100). It is not merely that Hume thinks that theological dogmas, idle reveries of the imagination, astrological perambulations and the like are false; he denies that the their affirmations of external existence are even possible; indeed, Newtonian, empirical science gives us every reason to believe that those affirmations are absurd. We have sufficient reason by the experimental method to affirm the invalidity of those methods and to reject their existence claims. I believe that all this in part explains the radical, proto-positivist last words of $A n$ Enquiry Concerning Hume an Understanding:

When we run over libraries, persuaded of these principles, what havoc must we make? If we take in our hand any volume, of divinity or school metaphysics, for instance, let us ask, Does it contain any abstract reasoning, concerning quantity or number? No Does it contain any experimental reasoning concerning a matter of fact? No Commit it then to the flames. For it can contain nothing but sophistry and illusion (Hume, 1748: p. 123).

\section{Conclusion}

Hume would have bridled at any Quinean intimation of idealism in his own philosophy. There is more to reality than our own impressions and ideas, but there isn't much more. Hume, I believe is best characterized as an empiricist and minimal realist. For Hume, the answer to the ontological question is that every thing exists. Those things are impressions and ideas, and any other "things" that we rightly endorse by the method of experimental reasoning, which validates 
relative ideas of them and the relative ideas of their external existence. Those "things" include body, bodies (viz, physical objects), their properties and relations, like motion, instantaneous velocity, acceleration as well as related physical phenomena, notably light. Putative entities like God, space, and time, and even the self (a sanitized version of the soul), are not up to standard-in the case of the self, at least not yet.

\section{Limitations and Next Steps}

What is missing (and is the next step) in the development of this line of thinking about Hume is to connect observations about external existence with Hume's semantics and epistemology, both of which are laid out at the beginning of the fourth section of the Enquiry Concerning Human Understanding (Hume, 1748, 4.1-24, pp. 24f.) There Hume distinguishes "relations of ideas" from "matters of fact." Relations of ideas are "discoverable by the mere operation of thought" and are hence "a priori," as Kant would say. Hume claims that the Pythagorean Theorem and "that the product of three and five is the half of thirty" are good examples of "relations of ideas." Relations of ideas are contrasted with matters of fact. Matters of fact have "contraries" ("negations," as we would say) that are "ever so conformable to reality." By this Hume means that existence claims are contingent since both each claim and its negation are consistent with the nature of reality. This suggests the conclusion, which Kant rejects, that the classes of matters of fact and relations of ideas are mutually exclusive, in which case there are no judgments in the a priori category that are also in the matters of fact category. Nothing about actual existences can be discovered by the mere operation of thought. Supposing that to be true, it would easy to see why Hume would have been inclined to rule out the possibility that there could be "anything of value in divinity or school metaphysics."

The ideas of an infinite God and of the finite self (and incontrovertibly, the soul) do not appear to be derived from experience; yet reasonable people (like Newton) who faithfully adhere to experimental reasoning, claim that they nevertheless do have those ideas. So, the obvious question is how to explain those ideas without legitimizing them. Hume's answer is that whatever we think of those iconic notions of metaphysics, the experimental method of reasoning does not itself yield even the relative idea of their external existence. Even so, those who followed Hume, especially Kant, were not satisfied that the underlying puzzles about those concepts, especially space and time, were satisfactorily addressed by Hume. For some time, it appeared to many that the truths of mathematics and even of the most fundamental truths mathematical physics are a priori, necessary, and nonetheless about the world.

Further progress in developing the present inquiry include the examinations of Hume's views about the reasonableness of our beliefs about the future as well as the reasonableness of the decisions that we make about what to do, which in turn are based upon our beliefs about the future. The reasonableness of our 
choices forces us to confront our ideas about the criteria of reasonableness by which we judge our choices. What indeed could possibly make decisions based upon those beliefs reasonable? We have reasons based upon the experimental method for believing facts warranted about the existence of bodies and their properties, but we also have reasons based upon the experimental method for choosing courses of action commended by the rational mind. In deciding what to do (and to be), we must account for the consequences of our decision, and therefore we must calculate both the value and the probability of outcomes. The next step is to analyze what Hume thinks that the experimental method of the natural sciences teaches us about those calculations.

\section{Conflicts of Interest}

The author declares no conflicts of interest regarding the publication of this paper.

\section{References}

Boyer, C. (1968). A History of Mathematics. New York: John Wiley and Sons.

Descartes, R. (1641). Meditations on First Philosophy (Vol. II, Cottingham, J. et al. Trans. and Eds.). Cambridge: Cambridge University Press, 1985.

Descartes, R. (1644). Principles of Philosophy (Cottingham, J. et al. Trans. and Eds.). Cambridge: Cambridge University Press, 1985.

Hitchcock, C. (2018). Probabilistic Causation. Stanford Encyclopedia of Philosophy. https://plato.stanford.edu/entries/causation-probabilistic

Hume, D. (1740). Treatise of Human Nature. Oxford: Clarendon Press, 2007. https://doi.org/10.1093/oseo/instance.00046221

Hume, D. (1748). An Enquiry Concerning Human Understanding. Oxford: Clarendon Press, 2006. https://doi.org/10.1093/oseo/instance.00032980

Hume, D. (1776). Dialogues Concerning Natural Religion. New York: Bobbs-Merrill, 1947.

Kant, I. (1781). Immanuel Kant's Critique of Pure Reason (Norman Kemp Smith, Trans.). New York: St. Martin's Press (Macmillan), 1929.

Leibniz, G. (1714). Monadology. In R. Ariew, \& E. Watkins (Eds.), Modern Philosophy, An Anthology of Primary Sources (2nd ed., Robert Ariew and Daniel Garber, Trans., pp. 275-283). Indianapolis/Cambridge: Hackett Publishing Company, 2009.

Levin, J. (2018). Functionalism. Stanford Encyclopedia of Philosophy. https://plato.stanford.edu/entries/functionlism

Lobachevsky, N. (1829). On the Principles of Geometry. Kazan Messenger.

Locke, J. (1689). An Essay Concerning Human Understanding. Oxford: Oxford University Press. (New York, Dover, Unaltered Edition, 1959) https://doi.org/10.1093/oseo/instance.00018020

Lyotard, J.-F. (1984). La Condition postmodern; Rapport sur le savoir (Bennington Geoff and Brian Massumi, Trans., pp. 3-17). Minneapolis, MN: University of Minnesota Press, 1984.

Mossner, E. (1980). The Life of David Hume (2nd ed.). Oxford: Clarendon Press.

Newton, I. (1692). Letter to Bentley II. In Thayer (Ed.), Newton's Philosophy of Nature 
(pp. 50-53). New York: Haffner/Macmillan Publishing Co., 1953.

Newton, I. (1693). Letter to Bentley IV. In Thayer, (Ed.), Newton's Philosophy of Nature (pp. 57-58). New York: Haffner/Macmillan Publishing Co., 2009.

Newton, I. (1713). Optics. In R. Ariew, \& E. Watson (Eds.), Modern Philosophy: An Anthology of Primary Sources (Motte, Trans., 2nd ed., pp. 291-294). Indianapolis/Cambridge: Hackett Publishing Company, 2009.

Newton, I. (1714). The Mathematical Principles of Natural Philosophy. In R. Ariew, \& E. Watson (Eds.), Modern Philosophy: An Anthology of Primary Sources (Motte, Trans., 2nd ed., pp. 291-294). Indianapolis/Cambridge: Hackett Publishing Company, 2009.

Ott, W. (2009). Causation and Laws of Nature in Early Modern Philosophy. New York: Oxford University Press. https://doi.org/10.1093/acprof:oso/9780199570430.001.0001

Quine, W. V. O. (1954). The Scope and Limits of Science. In: W. V. O. Quine (Ed.), The Ways of Paradox and Other Essays (pp. 215-232). New York: Columbia University Press, 1969.

Quine, W. V. O. (1960). Epistemology Naturalized. In: W. V. O. Quine (Ed.), The Ways of Paradox and Other Essays (pp. 26-68). New York: Columbia University Press, 1969.

Quine, W. V. O. (1964). On What There Is. In W. V. O. Quine (Ed.), From a Logical Point of View (pp. 1-19). Cambridge, MA: Harvard University Press.

Quine, W. V. O. (1968). Ontological Relativity. In W. V. O. Quine (Ed.), Ontological Relativity \& Other Essays (pp. 26-68). New York: Columbia University Press, 1969.

Robinson, W. (2019). Epiphenomenalism. https://plato.stanford.edu/entries/epiphenomenalism

Russell, P. (2008). The Riddle of Hume's Treatise: Skepticism, Naturalism and Irreligious. New York: Oxford University Press.

Zhuangzi (Zhuang Zhou) (c. 300 BCE). Burton Woods (Trans.) Basic Writings (3rd ed.). New York: Columbia University Press, 1964. 